\author{
ACTA MYCOLOGICA \\ Vol. 43 (1): 99-103 \\ 2008
}

\title{
Autofluorescence of ascospores and conidial spores in selected lichen species of the Opegrapha genus
}

\author{
ANETTA WIECZOREK \\ Department of Ecology, University of Szczecin \\ Wąska 13, PL-71-415 Szczecin, anettaw@univ.szczecin.pl
}

Wieczorek A.: Autofluorescence of ascospores and conidial spores in selected lichen species of the Opegrapha genus. Acta Mycol. 43 (1): 99-103, 2008.

The paper presents findings of the research work on autofluorescence phenomenon in ascospores and conidial spores that was carried out on 12 selected species of the Opegrapha genus occurring in Poland.

Key words: lichens, Opegrapha, autofluorescence

\section{INTRODUCTION}

Autofluorescence is one of luminescence types and consists in emitting the own light, which is induced by photon capture by a body. Own luminescence of cells depends on the presence of endogenous chromophores in tissue. The phenomenon of autofluorescence is frequent not only in plants but also in fungi (Rost 1992). It has been observed, among others, in the cytoplasm of ascospore and konidial spore hyphae (Žižka, Gabriel 2006). Studies on the usefulness of autofluorescence methods in identification of fungi species are used in examination of mycorrhiza phenomenon (Séjalon-Delmas et al. 1998) and in laboratory diagnostics, in particular of pathogenic fungi, and consist among other in determination of tissue colour differences in healthy plants and animals and those pathologically changed (Margo, Bombardier 1985; Elston 2001). In lichens, autofluorescence phenomenon has been used, among others, in evaluation of the viability of hyphae and algal cells according to the method of their storage (Honegger 2003) as well as in evaluation of damages in the chlorophyll apparatus of algal cells induced by high pollutant concentration (Favali et al. 1991; Silberstein et al. 1996). Sometimes, this phenomenon can be used for determining germination capacity (Cathy, Warren 1984). This study aimed at taking up an attempt to use the autofluorescence phenomenon in identification of lichen species of the Opegrapha genus. 


\section{MATERIAL AND METHODS}

In the study were used selected epiphytic and epilitic species of the Opegrapha genus occurring in Poland (O. atra Pers., O. calcarea Sm., O. culmigena Lib., O. dolomitica (Arnold) Clauzade \& CL. Roux, O. gyrocarpa Flot., O. niveoatra (Borrer) J. R. Laundon, O. rufescens Pers., O. rupestris Pers., O. varia Pers., O. vermicellifera (Kunze) J. R. Laundon, O. viridis (Ach.) Behlen \& Desberger, and $O$. vulgata (Ach.) Ach. Species terminology was adopted after Santesson et al. (2004) and Dietrich et al. (2008). In order to determine the intensity of autofluorescence, a series of microscope slides was prepared, 10 samples per each species, using the fresh material collected by the author from the bark of different tree species within the area of the western Poland in 2004-2006 as well as the herbarium material. The samples collected from the herbarium material were from 1940-2001. In order to examine in detail the subtle structures, such as ascospores and conidial spores, squashed microscope slides were prepared. In the study, a LSM 510 laser scanning microscope (Zeiss), operating on an Axiovert 200M motorised inverted microscope with fluorescence (Zeiss), was used. The used laser was an argon-ion laser with $11 \%$ power output, emitting $488 \mathrm{~nm}$ light waves, equipped with a $63 \mathrm{x}$ objective for ascospores and a 100x objective for conidial spores and two red filters (between $505 \mathrm{~nm}-650 \mathrm{~nm}$ wavelength) and one green filter (to $505 \mathrm{~nm}$ wavelength); when observing ascospores and conidial spores, a Nomarski filter was used.

\section{RESULTS AND DISCUSSION}

In all examined species, the emission of light within the wavelength range from $488 \mathrm{~nm}$ to $505 \mathrm{~nm}$, and sometimes over $650 \mathrm{~nm}$, was found (Tab. 1). The examined taxa were separated into three groups with different fluorescence intensity. The ascospores of the following species were in the first group: O. atra (Fig. 1), O. calcarea, O. dolomitica (Fig. 2) and O. rupestris (Fig. 3), with the fluorescence intensity within both wavelength ranges being clearly observable. In the second group, the spores of O. gyrocarpa, O. vermicellifera, $O$. vulgata (Fig. 4), O. viridis and $O$. culmigena were found, the autofluorescence intensity of which was much weaker or almost completely inconspicuous. In case of the species of the second group, no expected effects were obtained despite intensification of autofluorescence with ultraviolet radiation. On the other hand, a more rapid burning of autofluorescence was observed after application of ultraviolet radiation.

Into the third group, the ascospores of such species as O. niveoatra, O. varia (Fig. 5 ) and $O$. rufescens (Fig. 6) were included, in which a variable intensity of fluorescence was found. Different level of autofluorescence intensity in these species can be induced on the one hand by a different depth of spore location in microscope slide but on the other hand by a different degree of ascospore maturity.

It should be emphasised that observation of spores at the stage of transversal wall formation (Figs 7-9) in the taxa with weak autofluorescence showed the occurrence of such phenomenon.

In the species with intense autofluorescence, a fading of red light emission was observed as deeper spore layers were scanned due to autofluorescence burning. 
Table 1

Autofluorescence intensity of ascospores in selected lichen species of the Opegrapha genus

\begin{tabular}{|c|c|c|c|}
\hline \multirow[t]{3}{*}{ Species } & \multicolumn{3}{|c|}{$\begin{array}{l}\text { Light emission intensity within } \\
\text { wavelength range }\end{array}$} \\
\hline & $488-659 \mathrm{~nm}$ & & \\
\hline & High & Weak & Very weak \\
\hline O. atra Pers. & + & & \\
\hline O. calcarea $\mathrm{Sm}$. & + & & \\
\hline O. dolomitica (Arnold) Clauzade \& CL. Roux & + & & \\
\hline O. rupestris Pers. & + & & \\
\hline O. varia Pers. & + & + & \\
\hline O. rufescens Pers. & + & + & + \\
\hline O. niveoatra (Borrer) J. R. Laundon & & + & + \\
\hline O. gyrocarpa Flot. & & + & \\
\hline O. vermicellifera (Kunze) J. R. Laundon & & + & \\
\hline O. vulgata (Ach.) Ach. & & + & \\
\hline O. viridis (Ach.) Behlen \& Desberger & & & + \\
\hline O. culmigena Lib. & & & + \\
\hline
\end{tabular}

No fundamental differences were observed in the intensity of spore fluorescence in microscope slides prepared both from the fresh and herbarium materials.

The conidial spores of all examined species showed similar autofluorescence, irrespective of the origin of the analysed material and their size (Figs 10-12).

The taken up research is the first attempt of using autofluorescence phenomenon for identification of lichen species of the Opegrapha genus. The carried out analyses showed the presence of endogenous chromophores in the cytoplasm of ascospres and conidial spores in all examined taxa. In the literature a correlation was showed between the fluorescence intensity and the viability, maturity degree and storage conditions of ascospores and conidial spores (Cathy, Warren 1984; Honegger 2003). It was also proved that the fluorescence intensity of algal cells changed depending on the degree of environmental pollution (Di Toppi et al. 2005) and other factors. In the work by Favali et al. 1991, not only changes in autofluorescence intensity connected with the harmful effect of such chemical elements as aluminium (Al), silicon $(\mathrm{Si})$, phosphorus $(\mathrm{P})$, sulphur $(\mathrm{S})$, chlorine $(\mathrm{Cl})$, and calcium $(\mathrm{Ca})$ were demonstrated but also differences were showed in the concentration of respective chemical elements in different elements of the thallus, including a considerable concentration of aluminium in the apothecia. It is not excluded that these stress factors could also affect the intensity of light emission in ascospores and conidial spores. Autofluorescence depends also on the type and the amount of chromophore occurring in the cytoplasm. The carried out analyses of images show a variable autofluorescent response of ascospores in $O$. niveoatra, O. rufescens and $O$. varia. The spectrum of luminescence in the examined taxa may undergo changes and is not stable. Thus, it is difficult to determine simple criteria that would describe a given group of species, while autofluorescence intensity can not be a trait of diagnostic importance since it may be affected by many external factors. It appears thus that it is not a good method for identification of taxa, at least in that group of species. Nevertheless, it is worth expanding the research work on the usefulness of that method in taxonomic studies of other lichen and fungi genera. 


\section{CONCLUSIONS}

No fundamental taxonomic differences were found at the level of light emission intensity. The autofluorescent response of particular species results most probably from the size of spores and the same from the amount of cytoplasm inside them as well as from the degree of their maturity. As is showed by examinations, dead spores devoid of the cytoplasm as well as those being dormant do not show autofluorescence (Cathy, Warren 1984). The intensity of fluorescence in ascospores and conidial spores in the genus Opegrapha does not seem to be a good method in taxonomic identification of particular species.

Acknowledgements. I would like to thank Aleksander Ratajczak, MSc, from the Laboratory of Electron and Confocal Microscopy of the Adam Mickiewicz University in Poznań for his assistance and kindness with carrying out microscope observations as well as Prof. Krystyna Czyżewska (University of Łódź) for her valuable suggestions and comments during preparation of this paper.

\section{REFERENCES}

Cathy H. Wu., Warren H. L. 1984. Natural autofluorescence, and its correlation with viability. Mycologia 76 (6): 1049-1058.

Diederich P., Ertz D., Stapper N., Sérusiaux E., Ries C. 2008. The lichens and lichenicolous fungi of Belgium, Luxembourg and northern France. URL: http://www.lichenology.info [April 2008].

Di Toppi L.S., Musetti R., Vattuone Z., Pawlik-Skowrońska B., Fossati F., Bertoli L., Badiani M., Favali M. A. 2005. Cadmium distribution and effects on ultrastructureand chlorophyll status in photobionts and mycobionts of Xanthoria parietina. Microscopy Research and Technique 66 (5): 229-238.

Elston D.M. 2001. Fluorescence of fungi in superficial and deep fungal infections. BMC Microbiology 1: 21.

Favali M.A., Corradi M.G., Fossati F. 1991. X-Ray microanalysis and ultrastructure of lichens from polluted and unpolluted areas. Plants for Toxicity Assessment 2: 276-286.

Honegger R. 2003. The impact of different long-term storage conditions on the viability of lichen-forming Ascomycetes and their green algal photobiont, Trebouxia spp. Plant Biology 5 (3): 324-330.

Margo C. E., Bombardier T. 1985. The diagnostic value of fungal autofluorescence. Survey of Ophthalmology 29: 374-376.

Rost F.W.D. 1992. Fluorescence microscop. Cambridge University Press, Cambidge, 267 pp.

Santesson R., Moberg R., Nordin A., Tønsberg T., Vitikainen O. 2004. Lichen-forming and lichenicolous fungi of Fennoscandia. Museum of Evolution, Uppsala University, 359 pp.

Séjalon-Delmas N., Magnier A., Douds D.D., Bécard G. 1998. Cytoplasmic autofluorescence of an arbuscular mycorrhizal fungus Gigaspora gigantea and nondestructive fungal observations in planta. Mycologia 90 (5): 921-926.

Silberstein L., Siegel B.Z., Siegel S.M., Mukhtar A., Galun M. 1996. Comparative studies on Xanthoria parietina, a pollution resistant lichen, and Ramalina duriaei, a sensitive species. I. Effects of air pollution on physiological processes. The Lichenologist 28: 355-365.

Žižka Z., Gabriel J. 2006. Primary fluorescence (autofluorescence) of fruiting bodies of the wood-rotting fungus Fomes fomentarius. Folia Microbiologica 51 (2): 109-113. 
Autofluorescencja zarodników workowych i konidialnych wybranych gatunków porostów z rodzaju Opegrapha

Streszczenie

W pracy przedstawiono wyniki badań nad zjawiskiem autofluorescencji zarodników workowych i konidialnych wybranych gatunków porostów z rodzaju Opegrapha. Zaobserwowano i scharakteryzowano zjawisko autofluorescencji u 12 gatunków występujących w Polsce $(O$. atra, $O$. calcarea, $O$. culmigena, $O$. dolomitica, $O$. gyrocarpa, $O$. niveoatra, $O$. rufescens, $O$. rupestris, $O$. varia, $O$. vermicellifera, $O$. viridis, $O$. vulgata).

W badaniach wykorzystano laserowy mikroskop skaningowy LSM 510 (Zaiss) pracujący na odwróconym mikroskopie Axiovert 200M (Zaiss) z fluorescencją. Zastosowano laser argonowy o mocy $11 \%$ wysyłający fale o długości $488 \mathrm{~nm}$, obiektyw $63 x$ dla zarodników workowych i 100x dla konidialnych oraz dwa filtry, czerwony o długości fal od 505 do $650 \mathrm{~nm}$ i zielony o długości, do $505 \mathrm{~nm}$. Przy obserwacji zarodników wykorzystano filtr nomarskiego. Nie stwierdzono zasadniczych różnic taksonomicznych w poziomie intensywności emisji światła. Zaobserwowane różnice w intensywności świecenia poszczególnych gatunków wynikają prawdopodobnie z wielkości, a tym samym ilości cytoplazmy wewnątrz zarodników oraz stopnia ich dojrzałości.

Po raz pierwszy opisano wykorzystanie zjawiska autofluorescencji w badaniach taksonomicznych porostów z rodzaju Opegrapha. Zaprezentowano pierwsze zdjęcia tego zjawiska, które uzupełniają oryginalny opis rodzaju. 